\title{
Removal of Magnesium from Aluminum Scrap by Compound-Separation Method Using Shirasu as an Additive
}

\author{
Tomokazu Hashiguchi* and Hidekazu Sueyoshi \\ Graduate School of Science and Engineering, Kagoshima University, Kagoshima 890-0065, Japan
}

\begin{abstract}
The removal of magnesium from the molten aluminum scrap containing magnesium was examined by compound-separation method. As an additive, three types of Shirasu (a natural resource in South Kyushu, Japan) with different particle sizes were used. The addition of Shirasu to the molten aluminum scrap at $1023 \mathrm{~K}$ resulted in the formation of $\mathrm{MgAl}_{2} \mathrm{O}_{4}$ and $\mathrm{MgO}$ by the reactions among $\mathrm{SiO}_{2}$ and $\mathrm{Al}_{2} \mathrm{O}_{3}$ in $\mathrm{Shirasu}$ and magnesium in the molten scrap. It was feasible to remove magnesium by separating these reaction products as dross. Assuming that all the Shirasu reacted with magnesium in the molten scrap, the amount of removed magnesium, which was calculated from these reactions, was in agreement with the measured one. In the addition of flaky Shirasu with a small particle size, the amount of removed magnesium increased linearly with agitation time after Shirasu addition. This is because the over-all reaction is mainly controlled by a surface-controlled reaction. In the addition of granular Shirasu with a large particle size, the increase in magnesium removal was parabolic. This is because the over-all reaction is mainly by a diffusion-controlled reaction. [doi:10.2320/matertrans.MBW200919]
\end{abstract}

(Received September 29, 2009; Accepted February 4, 2010; Published March 17, 2010)

Keywords: aluminum scrap, recycling, magnesium removal, Shirasu addition, compound-separation method

\section{Introduction}

The amount of energy required to manufacture aluminum ingots from aluminum scrap (about $7 \mathrm{MJ} / \mathrm{t}$ ) is significantly lower than that required when from ores (about $214 \mathrm{MJ} / \mathrm{t}$ ). ${ }^{1)}$ Thus, aluminum products have a high recycling efficiency. However, there is no well-established scrap screening system. Therefore, in the manufacture of aluminum ingots using aluminum scrap, the contamination of impurity elements occurs, resulting in the manufacture of low quality ingots. Thus, most of the recycled products are of a cascade recycling. ${ }^{2)}$ It is highly desirable to shift from cascade recycling to horizontal recycling.

Magnesium is one of the main impurity elements associated with cascade recycling. A large amount of magnesium is added to aluminum alloys to improve their mechanical properties, deformability and corrosion resistance. In the automobile industry, aluminum and magnesium alloys are now being used because the parts are of much lighter weight. One can predict that the magnesium contamination of aluminum ingots will become higher.

In the refining process for magnesium removal, $\mathrm{Cl}_{2}$ gas injection and flux treatment have been performed. ${ }^{3-5}$ ) However, $\mathrm{Cl}_{2}$ gas injection results in the generation of $\mathrm{HCl}$ gas which causes the production of dioxins. Maximum Achievable Control Technology (MACT) standards were established in the United State in 2000, and the use of $\mathrm{Cl}_{2}$ gas is now regulated. ${ }^{6}$ The reduction of $\mathrm{Cl}_{2}$ gas emission has also been established as an object of the refining industry in Japan. ${ }^{7)}$ Flux treatment as an alternative method has various problems such as the use of deleterious substances (chloride or fluoride), environmental damage due to the toxic gas produced during treatment and high cost. Therefore, the development of a new magnesium removal technology is desired. For the removal of impurity silicon from molten aluminum scrap a compound-separation method has been

*Graduate Student, Kagoshima University studied. ${ }^{8)}$ However, there have been no reports regarding removing impurity magnesium from the molten aluminum scrap.

In the present study, magnesium removal from aluminum scrap by compound-separation method, which has low environment impact and low cost, was examined. As an additive, Shirasu containing a large amount of $\mathrm{SiO}_{2}$, which exists in large quantity as a natural resource in South Kyushu, Japan and is harmless and inexpensive, was used. By removing the dross consisting of the compounds formed by the reaction between Shirasu and magnesium in the molten scrap, it was feasible to remove magnesium from the molten scrap. In this paper, these results are reported.

\section{Experimental Procedure}

As an aluminum scrap, aluminum alloy containing magnesium (JIS: A5083, Mg: 4.63 mass\%, Si: 0.11 mass\%, Fe: 0.25 mass $\%, \mathrm{Cu}: 0.05$ mass $\%, \mathrm{Mn}: 0.57$ mass $\%$, Ti: 0.02 mass \%, Cr: 0.12 mass \%, Zn: 0.02 mass $\%$, Al: Bal.) was used to identify the reaction between Shirasu and magnesium. The pieces of scrap had a plate shape $(50 \times 10 \times 4 \mathrm{~mm})$. As an additive, two kinds of Shirasu (AS-100 and KESB-03, Seishin Co. Ltd., Japan) were used. AS-100 was classified into two particle sizes $(<63 \mu \mathrm{m}$ and $63-150 \mu \mathrm{m})$ by sieving. Chemical compositions of the three types of Shirasu obtained by X-ray fluorescence analysis (XRF; ZSX100e, Rigaku Co. Ltd.) are shown in Table 1. Thus, primary component of Shirasu was $\mathrm{SiO}_{2}$ and the secondary component was $\mathrm{Al}_{2} \mathrm{O}_{3}$.

Figure 1 shows secondary electron (SE) images of Shirasu observed by scanning electron microscopy (SEM; XL30CP, FEI Co. Ltd.) with an energy dispersive X-ray analyzer (EDX). As shown in Fig. 1(a), the shape of small Shirasu (AS-100) was a flake. As shown in Figs. 1(b) and (c), a thickness of the Shirasu was about $20 \mu \mathrm{m}$. Shirasu (KESB03 ) with a large particle size $(300-590 \mu \mathrm{m})$ was a mixture of flake and nodule. X-ray diffraction (XRD) analysis revealed that Shirasu is amorphous. 
Table 1 Chemical compositions of Shirasu (mass\%).

\begin{tabular}{|c|c|c|c|c|c|c|c|c|c|c|}
\hline \multirow{2}{*}{ Shirasu } & \multirow{2}{*}{$\begin{array}{l}\text { Particle size } \\
(\mu \mathrm{m})\end{array}$} & \multicolumn{9}{|c|}{ Chemical compositions } \\
\hline & & $\mathrm{SiO}_{2}$ & $\mathrm{Al}_{2} \mathrm{O}_{3}$ & $\mathrm{~K}_{2} \mathrm{O}$ & $\mathrm{Na}_{2} \mathrm{O}$ & $\mathrm{Fe}_{2} \mathrm{O}_{3}$ & $\mathrm{CaO}$ & $\mathrm{MgO}$ & $\mathrm{TiO}_{2}$ & $\mathrm{P}_{2} \mathrm{O}_{5}$ \\
\hline \multirow{2}{*}{ AS-100 } & $<63$ & 73.3 & 14.2 & 3.94 & 3.10 & 2.77 & 1.60 & 0.321 & 0.240 & 0.0235 \\
\hline & $63-150$ & 74.9 & 13.3 & 4.07 & 3.29 & 2.34 & 1.31 & 0.214 & 0.184 & 0.0196 \\
\hline KESB-03 & $300-590$ & 73.5 & 14.0 & 4.13 & 3.23 & 2.65 & 1.52 & 0.280 & 0.208 & 0.0229 \\
\hline
\end{tabular}
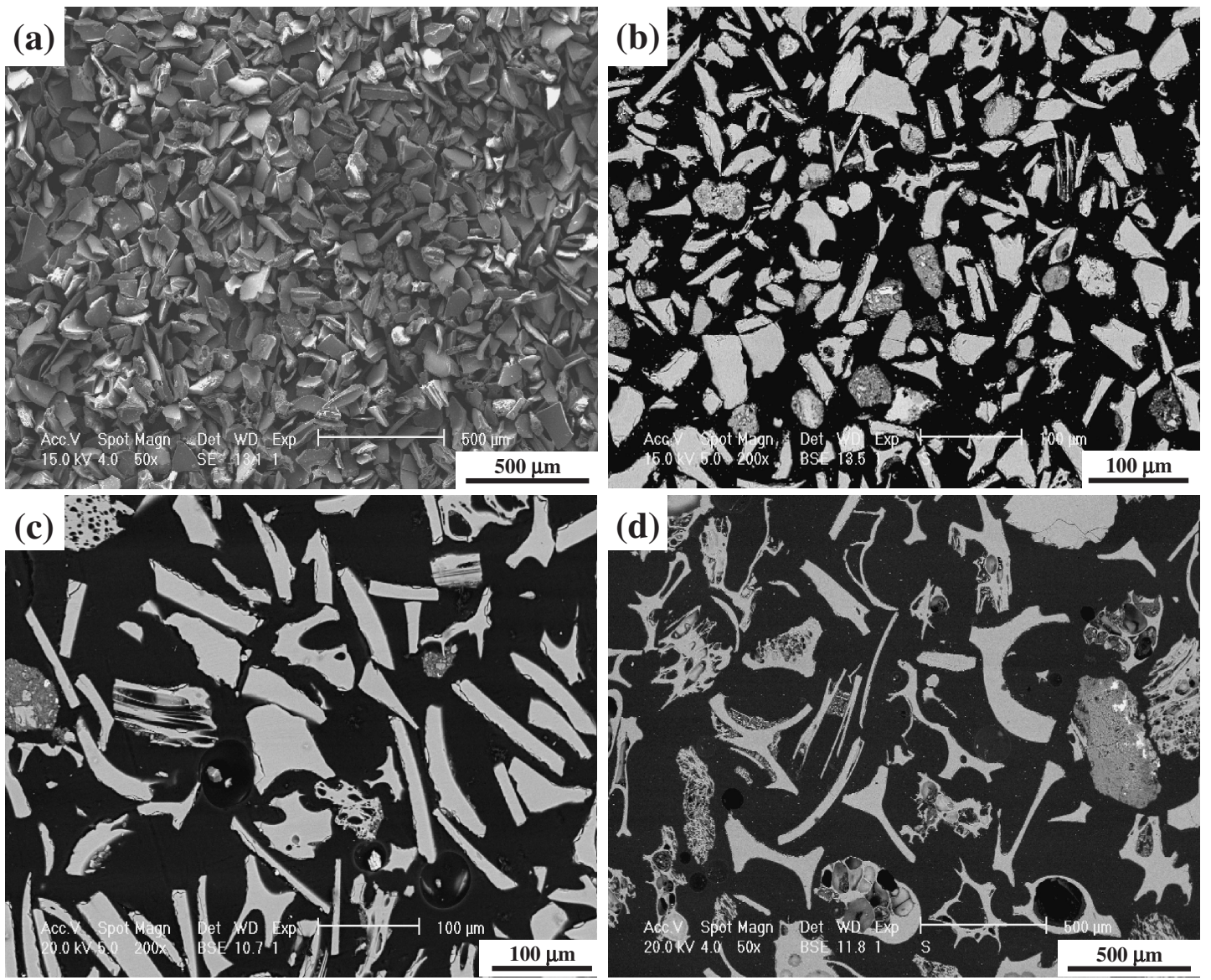

Fig. 1 SE images of Shirasu. (a) Shirasu AS-100, (b) cross section of Shirasu with a particle size of $<63 \mu \mathrm{m}$, (c) cross section of Shirasu with a particle size of $63-150 \mu \mathrm{m}$ and (d) cross section of Shirasu with a particle size of $300-590 \mu \mathrm{m}$.

The aluminum scrap was dissolved in a carbon crucible under air ambient. Shirasu (7 mass\%) lagged with aluminum foil was added to the molten scrap at $1023 \mathrm{~K}$, which was followed by agitation for various lengths of time. Dross floating on the surface of the molten scrap was skimmed off and then the molten scrap was poured into a steel mold. The reaction products which settled on the crucible bottom (settled dross) were also collected. The magnesium and silicon contents of the ingot were examined by XRF. The microstructures of the ingot and dross were observed by SEM with EDX. In order to identify the reaction products, the dross was examined by XRD.

\section{Results}

Figure 2 shows the relationship between magnesium content in the ingot and agitation time. Because the experiments were performed under air ambient, one can predict that magnesium content decreases following the reaction between magnesium in the molten scrap and oxygen gas in the atmosphere, that is, $\mathrm{MgO}$ is formed. Therefore, the change in the magnesium content of the ingot produced by agitation only without Shirasu addition is also shown in Fig. 2 (indicated by $\boldsymbol{\Delta}$ ). There was little reduction in the magnesium content in the case of agitation only without Shirasu addition. On the other hand, Shirasu addition resulted in a decrease in magnesium content of the ingot. In the addition of Shirasu with small particle sizes $(<63 \mu \mathrm{m}$ and $63-150 \mu \mathrm{m})$, each magnesium content decreased linearly with agitation time. However, there was no different in the effect of particle size on magnesium removal. In the addition of Shirasu with a large particle size $(300-590 \mu \mathrm{m})$, the decrease in magnesium content was parabolic.

Figure 3 shows the relationship between silicon content in the ingot and agitation time. The silicon content increased until $20 \mathrm{~min}$ of agitation time but saturated when the agitation 


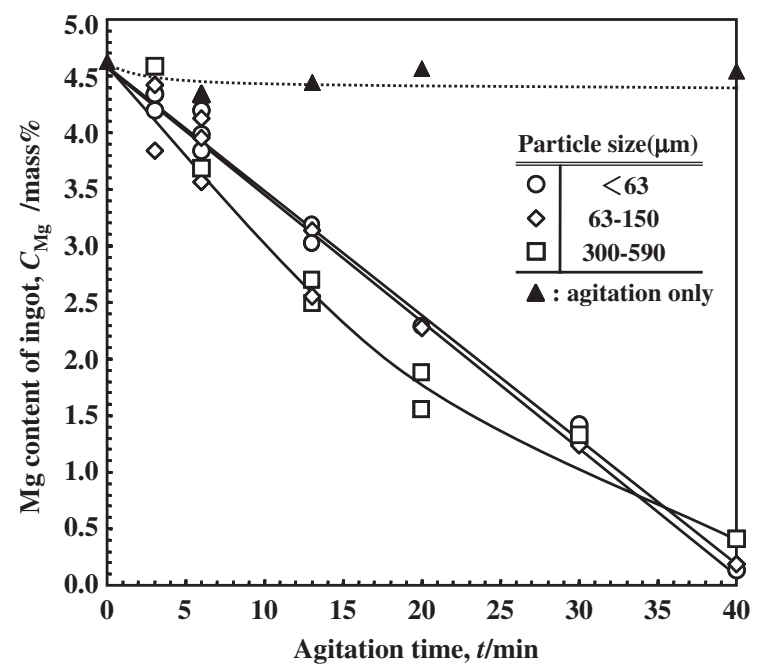

Fig. 2 Relationship between magnesium content in the ingot and agitation time.

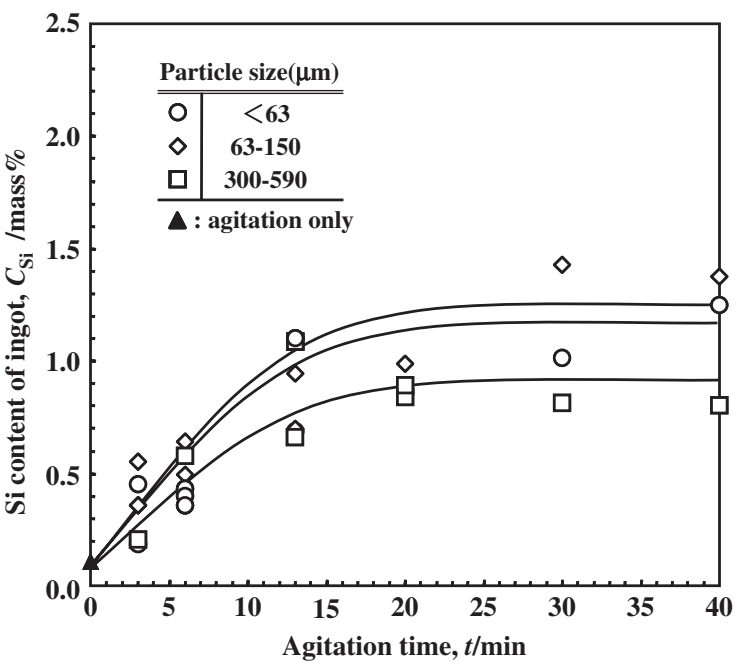

Fig. 3 Relationship between silicon content in the ingot and agitation time.
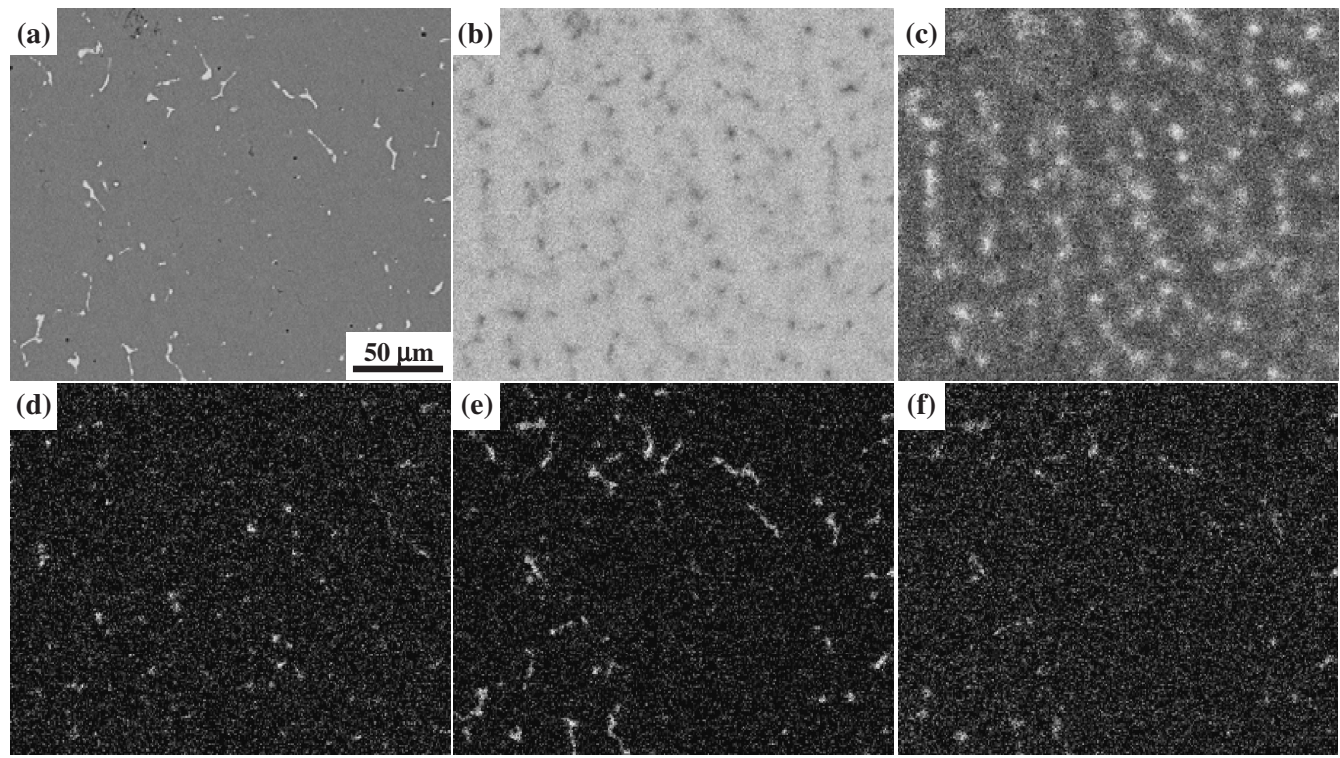

Fig. 4 The result of EDX analysis of the ingot produced by agitation only for 40 min without Shirasu addition. (a) BSE image, (b) Al K $\alpha$ ray image, (c) $\mathrm{Mg} \mathrm{K} \alpha$-ray image, (d) Si K $\alpha$-ray image, (e) $\mathrm{Fe} \mathrm{K} \alpha$-ray image and (f) $\mathrm{Mn} \mathrm{K} \alpha$-ray image.

time exceeded $20 \mathrm{~min}$. The silicon content saturated in the addition of Shirasu with a large particle size $(300-590 \mu \mathrm{m})$ was smaller than those in the addition of Shirasu with small particle sizes $(<63 \mu \mathrm{m}$ and $63-150 \mu \mathrm{m})$.

Figure 4 shows the result of EDX analysis of the ingot produced by agitation only for $40 \mathrm{~min}$ without Shirasu addition. In $\mathrm{K} \alpha$-ray images, white shows that the atomic concentration is high. There was a part in which concentrated magnesium and silicon were detected. It is considered that this part is $\mathrm{Mg}-\mathrm{Si}$ compound $\left(\mathrm{Mg}_{2} \mathrm{Si}\right),{ }^{9)}$ which crystallized upon cooling to room temperature in the steel mold. On the other hand, macroscopically uniform distribution and micro-segregation of magnesium were detected, as shown in $\mathrm{Mg} \mathrm{K} \alpha$-ray image. This suggests that most of magnesium dissolve into the aluminum matrix. A white phase appeared at cell boundaries, as shown in back scattered electron (BSE) image. The $\mathrm{K} \alpha$-ray images and a quantitative analysis (point analysis) of the white phase revealed that this phase is an
Al-Si-Fe-Mn compound. Thus, no magnesium removal was achieved by agitation only without Shirasu addition.

Figure 5 shows the result of EDX analysis of the ingot produced by adding Shirasu with a particle size of $<63 \mu \mathrm{m}$ to the molten scrap, was followed by agitation for $40 \mathrm{~min}$. As shown in $\mathrm{Mg} \mathrm{K} \alpha$-ray image (Fig. 5(c)), there was little magnesium in the matrix. Concentrated magnesium and silicon owing to $\mathrm{Mg}_{2} \mathrm{Si}$ disappeared. These results correspond approximately to the magnesium content in the ingot (Fig. 2). There was marked increases in silicon at cell boundaries. This part corresponds to a white phase in BSE image. The $\mathrm{K} \alpha$-ray images and a quantitative analysis (point analysis) of the white phase revealed that this phase is an Al-Si-Fe-Mn compound. On the other hand, there was an area in which only silicon phase was detected, as shown in Fig. 5(d). These results suggest that the silicon produced by the dissociation of $\mathrm{SiO}_{2}$ dissolves into the molten scrap then precipitates as monolithic silicon and an Al-Si-Fe-Mn compound. 


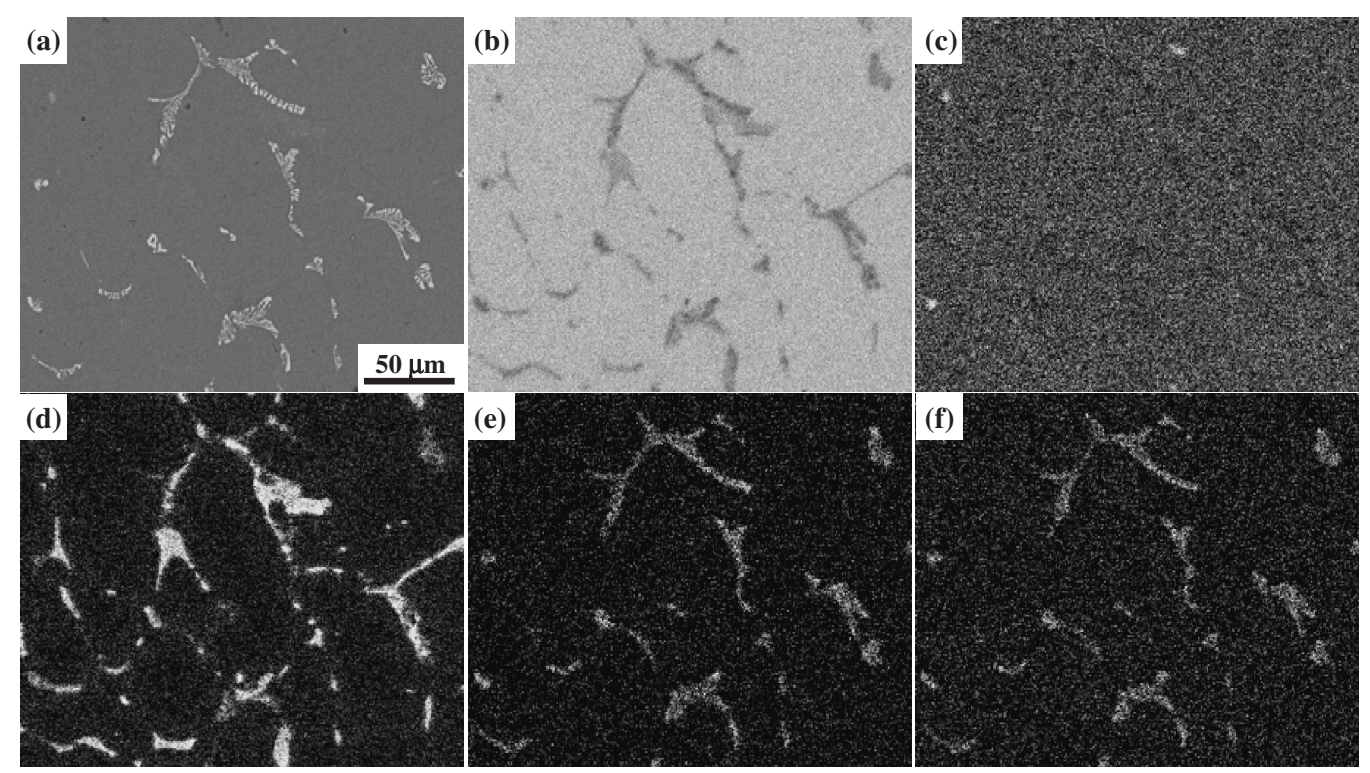

Fig. 5 The result of EDX analysis of the ingot produced by adding Shirasu with a particle size of $<63 \mu \mathrm{m}$ to the molten scrap, which was followed by agitation for $40 \mathrm{~min}$. (a) BSE image, (b) $\mathrm{Al} \mathrm{K} \alpha$-ray image, (c) $\mathrm{Mg} \mathrm{K} \alpha$-ray image, (d) Si K $\alpha$-ray image, (e) Fe K $\alpha$-ray image and (f) $\mathrm{Mn} \mathrm{K} \alpha$-ray image.
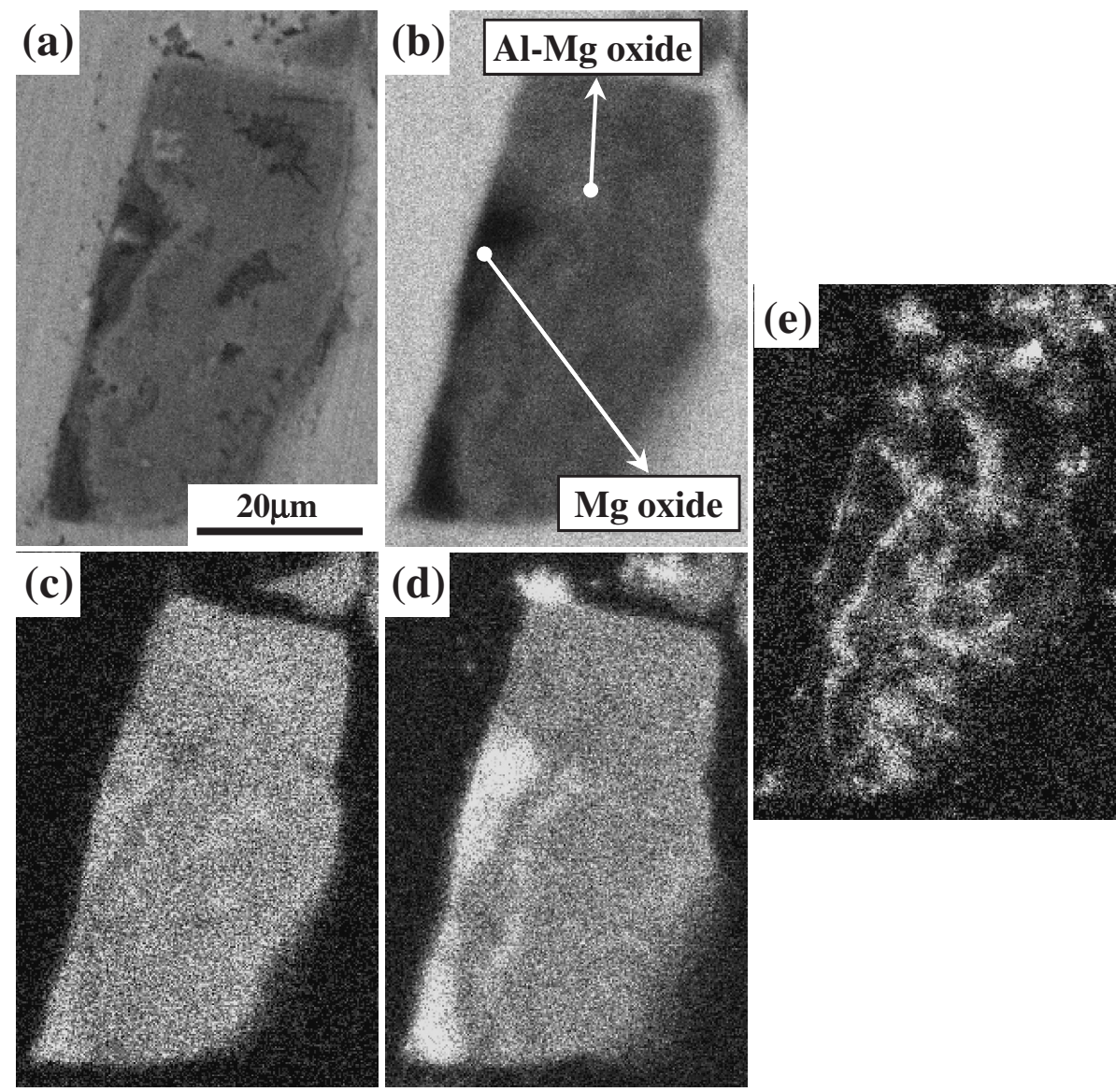

Fig. 6 The result of EDX analysis of the settled dross formed by adding Shirasu with a particle size of $<63 \mu \mathrm{m}$ to the molten scrap, which was followed by agitation for $40 \mathrm{~min}$. (a) BSE image, (b) $\mathrm{Al} \mathrm{K} \alpha$-ray image, (c) O K $\alpha$-ray image, (d) Mg K $\alpha$-ray image and (e) Si K $\alpha$-ray image.

Figure 6 shows the result of EDX analysis of the settled dross formed by adding Shirasu with a particle size of $<63 \mu \mathrm{m}$ to the molten scrap, which was followed by agitation for $40 \mathrm{~min}$. As shown in BSE image, the shape of reaction product was the same as Shirasu. As shown in $\mathrm{K} \alpha$-ray images, there was an area in which aluminum, magnesium and oxygen coexisted. This area consists of Al-Mg oxide. There was an area in which magnesium and oxygen 


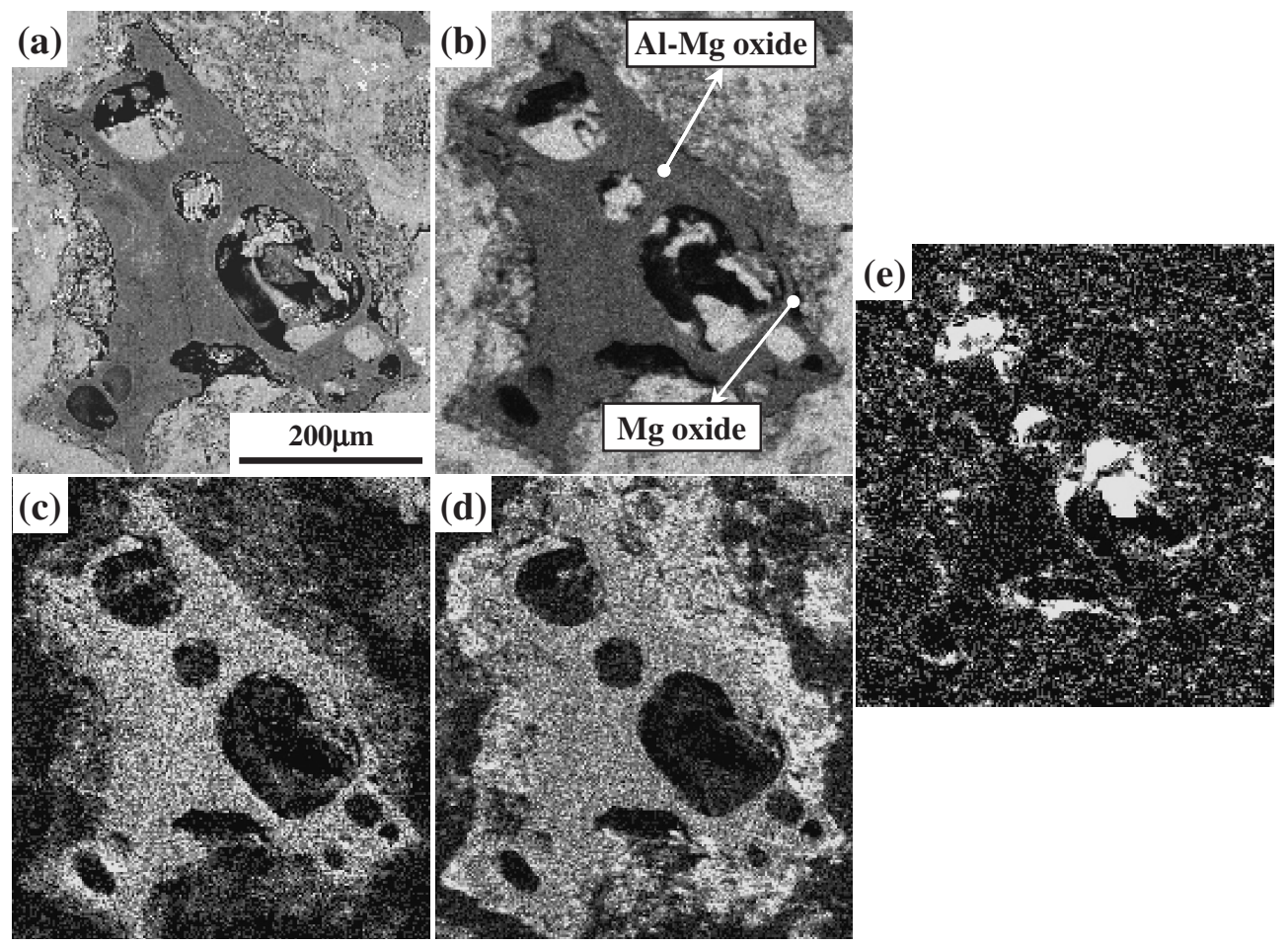

Fig. 7 The result of EDX analysis of the settled dross formed by adding Shirasu with a particle size of 300-590 $\mu \mathrm{m}$ to the molten scrap, which was followed by agitation for $40 \mathrm{~min}$. (a) BSE image, (b) Al K $\alpha$-ray image, (c) O K $\alpha$-ray image, (d) Mg K $\alpha$-ray image and (e) Si K $\alpha$-ray image.

coexisted. This phase is Mg oxide. As shown in Fig. 6(e), silicon was locally detected in the reaction product. This suggests that part of silicon produced by the dissociation of $\mathrm{SiO}_{2}$ remains in the reaction product without dissolving into the molten scrap. This is the reason why the silicon content in the ingot saturated when the agitation time exceeded 20 min as shown in Fig. 3.

Figure 7 shows the result of EDX analysis of the settled dross formed by adding Shirasu with a particle size of 300 $590 \mu \mathrm{m}$ to the molten scrap, which was followed by agitation for $40 \mathrm{~min}$. As mentioned above, $\mathrm{Al}-\mathrm{Mg}$ oxide and $\mathrm{Mg}$ oxide were observed. A number of areas in which silicon was concentrated were detected in the reaction product. This is because silicon placed inside the large-size Shirasu may be more difficult to be dissolved into the molten scrap. This is the reason why the silicon content of the ingot in the addition of Shirasu with a large particle size is lower than those in the addition of Shirasu with small particle sizes (Fig. 3).

Figure 8 shows XRD pattern of the settled dross formed by agitation for $40 \mathrm{~min}$ after Shirasu addition. Peaks of $\mathrm{MgAl}_{2} \mathrm{O}_{4}$ and $\mathrm{MgO}$ were detected. It has been reported in preparing aluminum matrix composites that the reactions among aluminum, magnesium and $\mathrm{SiO}_{2}$ results in the formation of $\mathrm{MgAl}_{2} \mathrm{O}_{4}$ and $\mathrm{MgO} .{ }^{10-12)}$ These results suggest that $\mathrm{Al}-\mathrm{Mg}$ oxide and $\mathrm{Mg}$ oxide observed in Figs. 6 and 7 are $\mathrm{MgAl}_{2} \mathrm{O}_{4}$ and $\mathrm{MgO}$, respectively. A peak of silicon phase was also detected. This indicates that the silicon which remains in the reaction product (Figs. 6 and 7) is a monolithic metal and not a compound. From XRD analysis of the ingot prepared by agitation for $40 \mathrm{~min}$ after Shirasu addition, peaks of $\mathrm{Mg}_{2} \mathrm{Si}$ and aluminum were detected though a peak of silicon phase disappeared.

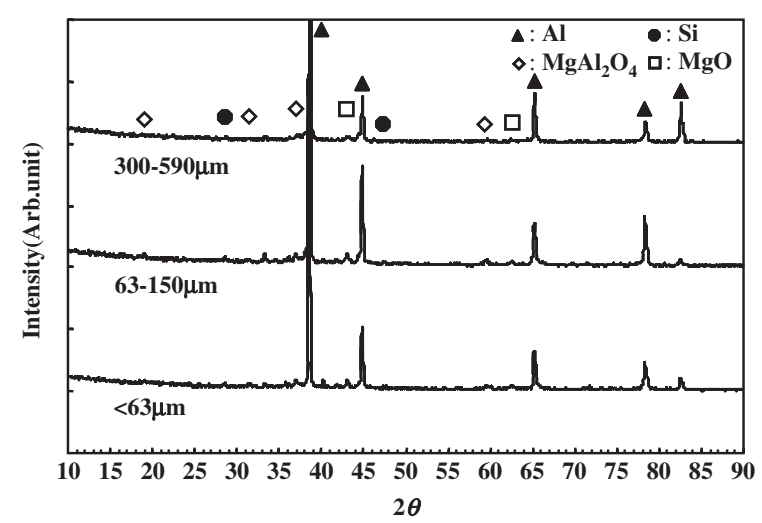

Fig. 8 XRD pattern of the settled dross formed by adding Shirasu to the molten scrap, which was followed by agitation for $40 \mathrm{~min}$.

\section{Discussion}

As mentioned above, the dross consists mainly of $\mathrm{MgAl}_{2} \mathrm{O}_{4}$ and $\mathrm{MgO}$. The reactions between Shirasu and the molten scrap can be summarized as

$$
\begin{aligned}
& 2 \mathrm{Mg}(\mathrm{l})+\mathrm{Al}_{2} \mathrm{O}_{3}(\mathrm{~s})+\mathrm{SiO}_{2}(\mathrm{~s}) \\
& \quad=\mathrm{MgO}(\mathrm{s})+\mathrm{MgAl}_{2} \mathrm{O}_{4}(\mathrm{~s})+\mathrm{Si}(\mathrm{s}) \\
& 2 \mathrm{Mg}(\mathrm{l})+\mathrm{SiO}_{2}(\mathrm{~s})=2 \mathrm{MgO}(\mathrm{s})+\mathrm{Si}(\mathrm{s}) \\
& \mathrm{MgO}(\mathrm{s})+2 \mathrm{Al}(\mathrm{l})+3 / 2 \mathrm{O}_{2}(\mathrm{~g})=\mathrm{MgAl}_{2} \mathrm{O}_{4}(\mathrm{~s})
\end{aligned}
$$

where $1=$ liquid, $\mathrm{s}=$ solid and $\mathrm{g}=$ gas. The standard Gibbs free energy $\left(\Delta G^{\circ}\right)$ for these reactions at $1023 \mathrm{~K}$ was calculated using HSC Chemistry Version 5. The values for reactions (1), (2) and (3) were $\Delta G_{\mathrm{I}}^{\circ}=-215 \mathrm{~kJ} / \mathrm{mol}$, 
$\Delta G_{\mathrm{II}}{ }^{\circ}=-202 \mathrm{~kJ} / \mathrm{mol}$ and $\Delta G_{\mathrm{III}}{ }^{\circ}=-1.383 \mathrm{MJ} / \mathrm{mol}$, respectively. In each reaction, the value of $\Delta G^{\circ}$ was negative. This suggests that the likelihood of achieving these reactions is high. As shown in Table 1, Shirasu had about 14 mass\% of $\mathrm{Al}_{2} \mathrm{O}_{3}$. The reaction (1) shows the reaction among the $\mathrm{SiO}_{2}$ and $\mathrm{Al}_{2} \mathrm{O}_{3}$ in Shirasu and magnesium in the molten scrap. The reaction (2) shows the reaction between $\mathrm{SiO}_{2}$ in Shirasu and magnesium in the molten scrap. Part of the $\mathrm{MgO}$ produced by reactions (1) and (2) reacts with $\mathrm{O}_{2}$, which is dissolved into the molten scrap by agitation, resulting in the formation of $\mathrm{MgAl}_{2} \mathrm{O}_{4}$ (reaction (3)). Because the density of Shirasu $\left(0.6-1.0 \mathrm{Mg} / \mathrm{m}^{3}\right)$ is smaller than that of Aluminum $\left(2.7 \mathrm{Mg} / \mathrm{m}^{3}\right)$, Shirasu added floats on the surface of the molten scrap. By agitation local reaction occur on the surface of Shirasu because of low wettability between Shirasu and the molten scrap. Shirasu with large unreacted parts floats on the surface of the molten scrap because the density is low compared with that of the molten scrap. On the other hand, most of the reaction products settle down to the crucible bottom because their densities $\left(\mathrm{MgAl}_{2} \mathrm{O}_{4}: 3.6 \mathrm{Mg} / \mathrm{m}^{3}\right.$ and $\mathrm{MgO}: 3.58 \mathrm{Mg} / \mathrm{m}^{3}$ ) are high compared with that of the molten scrap. Although large amounts of dross are generated in the present method, several methods to reuse the aluminium dross have been studied. ${ }^{13,14)}$

Assuming that all the Shirasu reacted with magnesium in the molten scrap by reactions (1) and (2), the content of residual magnesium $M_{\text {re }}$ (mass\%) is given by

$$
M_{\mathrm{re}}=C_{0}-\left(M_{1}+M_{2}\right)
$$

where $C_{0}$ is initial content of magnesium, $M_{1}$ and $M_{2}$ are the amount of magnesium removed by reactions (1) and (2), respectively. From reactions (1) and (2), $M_{1}$ and $M_{2}$ are given as

$$
\begin{aligned}
& M_{1}=\left(Q_{\mathrm{Al}_{2} \mathrm{O}_{3}} \cdot 2 M_{\mathrm{Mg}}\right) / M_{\mathrm{Al}_{2} \mathrm{O}_{3}} \\
& M_{2}=\left(Q_{\mathrm{SiO}_{2}} \cdot 2 M_{\mathrm{Mg}}\right) / M_{\mathrm{SiO}_{2}}
\end{aligned}
$$

where $Q_{\mathrm{Al}_{2} \mathrm{O}_{3}}$ (mass\%) is the amount of $\mathrm{Al}_{2} \mathrm{O}_{3}$ consumed by the reaction (1), $Q_{\mathrm{SiO}_{2}}$ (mass\%) is the amount of $\mathrm{SiO}_{2}$ consumed by the reaction (2) (initial amount of $\mathrm{SiO}_{2}$ minus the amount of $\mathrm{SiO}_{2}$ consumed by the reaction (1)) and $M_{\mathrm{Mg}}$, $M_{\mathrm{Al}_{2} \mathrm{O}_{3}}$ and $M_{\mathrm{SiO}_{2}}$ are molecular weight of $\mathrm{Mg}(24.3 \mathrm{~g} / \mathrm{mol})$, $\mathrm{Al}_{2} \mathrm{O}_{3}(102.0 \mathrm{~g} / \mathrm{mol})$ and $\mathrm{SiO}_{2}(60.1 \mathrm{~g} / \mathrm{mol})$, respectively. The value of $M_{\text {re }}$ calculated from eq. (4) and the amount of Shirasu added was 0.39 mass \%. This value is in agreement with the magnesium content of the ingot produced by agitation for $40 \mathrm{~min}$ (Fig. 2). This indicates that all the Shirasu reacted with magnesium in the molten scrap. This suggests that the amount of magnesium removed is also dependent on the amount of Shirasu added to the molten scrap.

As shown in Fig. 2, in the addition of small Shirasu, magnesium content of the ingot decreased linearly with agitation time. This suggests that reactions (1) and (2) are controlled by a surface-controlled reaction. This is because the reaction in the transverse direction of flaky Shirasu is achieved at a short time and Shirasu/molten scrap contact area increases with increasing agitation time though small- size Shirasu aggregates on the surface of the molten scrap. Thus, the over-all reaction is mainly controlled by the rate of the reaction along the surface of the flaky Shirasu. On the other hand, in the addition of large-size Shirasu, the decrease in magnesium content of the ingot was parabolic. It is well known that parabolic relationship between the amount of reaction and reaction time holds in a diffusion-controlled reaction. ${ }^{15)}$ This suggests that these reactions are controlled by a diffusion controlled reaction. This is because the overall reaction is mainly controlled by the diffusion rate in the transverse direction of granular Shirasu.

\section{Conclusions}

The removal of magnesium from the molten aluminum scrap containing magnesium was examined by compoundseparation method using Shirasu as an additive. The results obtained are as follows:

(1) The addition of Sirasu to the molten aluminum scrap results in the formation of $\mathrm{MgAl}_{2} \mathrm{O}_{4}$ and $\mathrm{MgO}$ by the reactions among $\mathrm{SiO}_{2}$ and $\mathrm{Al}_{2} \mathrm{O}_{3}$ in Shirasu and magnesium in the molten scrap. It is feasible to remove magnesium by separating these reaction products as dross.

(2) In the addition of flaky Shirasu with a small particle size, the amount of magnesium removed increases linearly with agitation time after Shirasu addition. This is because the over-all reaction is mainly controlled by a surface-controlled reaction.

(3) In the addition of granular Shirasu with a large particle size, the increase in magnesium removal is parabolic. This is because the over-all reaction is mainly by a diffusion-controlled reaction.

\section{REFERENCES}

1) T. Ohnishi: J. Japan Inst. Light Metals 46 (1996) 525-532.

2) A. R. Khoei, I. Masters and D. T. Gethin: J. Mater. Process. Thechnol. 127 (2002) 96-106.

3) K. Nishina: J. Japan Inst. Light Metals 41 (1991) 373-381.

4) R. R. Roy and Y. Sahai: Light Metals 1998, ed. by B. Welch (The Minerals, Metals and Materials Society, 1998) pp. 1237-1243.

5) T. A. Utigard, K. Friesen, R. R. Roy, J. Lim, A. Silny and C. Dupuis: J. Miner. Met. Mater. Soc. 50 (1998) 38-43.

6) K. A. Kitzman: Light Metals 2002, ed. by W. Schneider (The Minerals, Metals and Materials Society, 2002) pp. 849-854.

7) M. Tsunekawa: J. Japan Inst. Light Metals 54 (2004) 75-81.

8) M. Nagao and T. Nakamura: J. Japan Inst. Light Metals 46 (1996) 588-591.

9) Y. L. Liu, S. B. Kang and H. W. Kim: Mater. Lett. 41 (1999) 267-272.

10) M. Hanabe and P. B. Aswath: Acta Mater. 45 (1997) 4067-4076.

11) D. A. Weirauch, Jr.: J. Mater. Res. 3 (1988) 729-739.

12) V. M. Sreekumar, R. M. Pillai, B. C. Pai and M. Chakraborty: J. Alloy. Compd. 461 (2008) 501-508.

13) Y. Miyamoto: Curr. Opin. Solid State Mat. Sci. 7 (2003) 241-245.

14) J. Li, J. Wang, H. Chen, B. Sun and J. Jia: Abstracts. 9th Int. Conf. on Ecomaterials, (Ecomaterials Forum, 2009) pp. 109-110.

15) J. D. Verhoeven: Fundamentals of Physical Metallurgy, (John Wiley \& Sons, New York, 1975) pp. 137-168. 